MARTA MARCHOW

Uni-Terra Wyższa Szkoła

$w$ Poznaniu

\title{
TUTORING RÓWIEŚNICZY \\ A WSPOMAGANIE ROZWOJU \\ SPOŁECZNYCH MECHANIZMÓW UCZENIA SIĘ W WIEKU WCZESNOSZKOLNYM
}

ABSTRACT. Marchow Marta, Tutoring rówieśniczy a wspomaganie rozwoju społecznych mechanizmów uczenia się w wieku wczesnoszkolnym [Peer Tutoring and Enhancing Social Learning Strategies in Early School Age]. Studia Edukacyjne nr 36, 2015, Poznań 2015, pp. 235-249. Adam Mickiewicz University Press. ISBN 978-83-232-2958-2. ISSN 1233-6688. DOI: 10.14746/se.2015.36.14

Peer tutoring, as an educational strategy in one-to-one relations, is based on the collaboration between a lower- and a higher-performing students. Though both the tutor and the tutee roles enhance social learning strategies, I particularly focus on some developmental effects of tutors' performance. The tutor's role seems to have a special impact on the development of thought monitoring and on the awareness of the social demands of instruction. Differences in competences between children are a stimulating factor in promoting social learning strategies development. The process is strongly mediated by the theory of mind in students and thus influences further educational achievements. Moreover, peer tutoring does not seem to be less effective as a spontaneous interaction between children as compared to tutoring organized and monitored by adults.

Key words: Peer Tutoring, Zone of Proximal development, Theory of mind, Differences in competences Between Students, Social Learning Strategies

\section{Wprowadzenie}

Opanowując narzędzia potrzebne do funkcjonowania w danej kulturze, człowiek nie tylko staje się użytkownikiem samych narzędzi, ale również istotą posługującą się nimi wobec innychํ․ Zatem, potrafi nie tylko czytać,

${ }^{1}$ L.S. Wygotski, Wybrane prace psychologiczne, Warszawa 1971. 
pisać, czy liczyć, ale za pomocą tych umiejętności potrafi rozwiązywać istotne dla siebie problemy. Bez opanowania czytania, pisania, czy liczenia dzieci nie będą potrafiły się później uczyć innych, bardziej skomplikowanych treści, toteż traktuje się je jako podstawę wszelkiej edukacji szkolnej. Ale ucząc się ich, dzieci muszą wchodzić w interakcje społeczne; sam proces przyswajania tych narzędzi intelektualnych jest zanurzony $w$ systemie aktywnej współpracy $\mathrm{z}$ innymi. Uczestniczenie $\mathrm{w}$ interakcjach edukacyjnych rozwija dziecko nie tylko jako istotę płynnie czytającą, ale również jako istotę, która potrafi korzystać z sytuacji uczenia się, robić pożytek ze wskazówek nauczyciela, czy z wymiany doświadczeń między rówieśnikami. Dalej, dzięki temu procesowi rozwija ono kompetencje $\mathrm{w}$ zakresie strategii nabywania wiedzy oraz refleksji nad tym procesem, $\mathrm{w}$ tym - nad własnym myśleniem. Chcę pokazać poniżej, że tutoring rówieśniczy może być obiecującą pod tym względem strategią.

\section{O tutoringu rówieśniczym}

Tutoring rówieśniczy wykorzystywany jest jako strategia wspomagająca klasyczną edukację dzieci w relacji nauczyciel - klasa². Podejmuje się próby opracowania takich programów we współpracy szkół z placówkami badawczymi, weryfikuje się ich efekty, wybiera bardziej skuteczne układy interakcyjne $^{3}$. Tutoring rówieśniczy opiera się na interakcji jeden do jeden, to jest dzieci - rówieśnicy łączone są $\mathrm{w}$ pary. Interakcję tę charakteryzuje nierównorzędny status w zakresie kompetencji, gdzie bardziej kompetentna osoba pełni rolę tutora, a mniej kompetentna - ucznia lub też role te pełnione są $\mathrm{w}$ parach wymiennie ${ }^{4}$. W tutoringu ustala się oczekiwany poziom osiągnięcia umiejętności, który może być później przedmiotem obiektywnej, zewnętrznej oceny. Do zalet tutoringu rówieśniczego zalicza się między innymi: większą ilość czasu i uwagi poświęconą pojedynczemu dziecku, gdzie może ono liczyć na więcej powtórzeń, więcej natychmiastowych informacji zwrotnych, indywidualnie skierowane instrukcje. Poza tym, zwraca się uwagę na bliskość i podobieństwo doświadczeń tutora i uczącego się, gdzie treści będące przedmiotem nauczania zyskują bliższy dzieciom kontekst

2 P. Rycielski, Efektywność ksztatcenia w programach tutoringu rówieśniczego, [w] Tutoring młodych uchodźców, publikacja elektroniczna, Warszawa 2012.

${ }^{3}$ K.L. McMaster, D. Fuchs, L.S. Fuchs, Promises and Limitations of Peer - Assisted Learning Strategies in Reading, Learning Strategies: A contemporary Journal, 2007, 5(2), s. 97-112.

${ }^{4}$ D. Fuchs, L.S. Fuchs, P. Burish, Peer Assisted learning Strategies: An evidence - based practice to promote reading achievement, Learning Disabilities Research and Practice, 2000, 15, s. 85-91. 
oraz wiarygodność5. Ważne jest też podobieństwo społecznego statusu tutora i uczącego się, co zachęca dzieci do bardziej odważnego zadawania pytań, ujawniania braku umiejętności czy odwrotnie, do ujawniania wiedzy czy umiejętności, których nie ośmieliłyby się ujawnić przy posiadającym miażdżącą przewagę dorosłym.

Tutoring rówieśniczy to nic innego, jak sposób organizacji interakcji edukacyjnej. To strategia stara i nowa jednocześnie. Stara, bo od zawsze dzieci uczyły się od siebie, w rodzinach, na podwórkach, we wspólnotach pierwotnych. Jest to sytuacja i naturalna, i atrakcyjna dla dzieci, i - jako możliwość kontaktu z rówieśnikami - bardzo ważna dla wszechstronnego rozwoju $\mathrm{w}$ tym wieku' ${ }^{6}$. Jest to pomysł nie nowy, ponieważ od lat w wielu krajach prowadzi się grupy i klasy z dziećmi w różnym, choć zbliżonym wieku, choćby w placówkach opartych na koncepcji Montessori ${ }^{7}$. Jednocześnie jest to strategia nowa, bo interakcje te są zaaranżowane w oparciu o efekty współczesnych i ciągle prowadzonych badań nad uczeniem się w kontekście społecznym. Tutoring rówieśniczy w klasie to nie tylko okazja do swobodnych interakcji między dziećmi. To również uczenie w sposób zorganizowany, z określoną strukturą zadaniową i zaaranżowanymi sytuacjami edukacyjnymi między tutorami i ich uczniami. Zupełnie spontaniczny, nieustrukturowany tutoring rówieśniczy może mieć wiele zalet w zakresie wspomagania rozwoju dzieci, ale często jest nieefektywny z punktu widzenia konkretnych

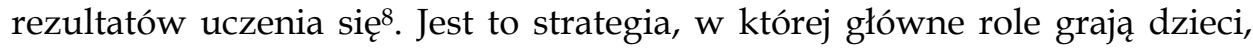
ale pieczę nad procesem sprawuje nauczyciel, będąc i punktem odniesienia dla oczekiwanych standardów, i dbając o wdrożenie efektywnych instrukcji wewnątrz interakcji rówieśniczych. Jest on więc głównym aranżerem kontekstu uczenia się, w tym - dla tzw. „rusztowania”9, jakie dzieci tworzą dla siebie nawzajem, opierając się na dostępnych dla siebie umiejętnościach, wiedzy i kompetencjach społecznych.

${ }^{5}$ P. Rycielski, Efektywność ksztatcenia; A. Brzezińska, Tutoring w edukacji: kaprys, konieczność czy szansa dla ucznia i nauczyciela? [w:] Tutoring mtodych uchodźców, publikacja internetowa, Warszawa 2012.

${ }^{6}$ J. Piaget. Studia z psychologii dziecka, Warszawa 1966; E.A Forman, C.B. Cazden, Myśl Wygotskiego a edukacja: wartości poznawcze wspótpracy z rówieśnikami, [w:] Dziecko wśród rówieśników $i$ dorostych, red. A. Brzezińska, G. Lutomski, B. Smykowski, Poznań 1995; H.R. Schaffer, Psychologia dziecka, Warszawa 2005.

7 J. Nowak, Tutoring rówieśniczy jako wsparcie rozwoju poznawczego dziecka, [w]: Dziecko i dorosty w koncepcji pedagogicznej Marii Montessori - teoria i praktyka, red. B. Surma, Łódź-Kraków 2009, s. 117-124.

8 D. Fuchs, L.S. Fuchs, I.P. Burish, Peer Assisted learning Strategies, s. 85.

9 J. Radziszewska, B. Rogoff, Children's guided participation in planning imaginary errands with skilled adult or peer partners, Developmental Psychology, 1991, 27, 3, s. 381; H.R. Schaffer, Psychologia dziecka, Warszawa 2005. 


\section{Uczenie się w kontekście społecznym a różnica kompetencji w interakcjach edukacyjnych}

Różnica kompetencji jest kluczową ideą koncepcji strefy najbliższego rozwoju Wygotskiego ${ }^{10}$. Jeśli interakcja ma prowadzić do rozwoju nowych form zachowania, to jej treścią nie powinno być to, co dziecko już doskonale umie, ani to, czego w żaden sposób nie jest w stanie wykonać, nawet wtedy, gdy mu się pomoże. $W$ procesie wspólnego wykonywania zadania osoba bardziej kompetentna aktywnie uczestniczy w interakcji, dostarcza środków i nowych doświadczeń do przezwyciężenia ograniczeń osoby mniej kompetentnej. Słowem, jest aktywnym organizatorem kontekstu uczenia się i udziela pomocy, daje uczącemu się odpowiednie wsparcie, a jeśli trzeba wprowadza zaburzenia $\mathrm{w}$ harmonijnym działaniu, aby sprowokować do nowych sposobów działania i powiązanego z nim myślenia ${ }^{11}$. To, co teraz jest wykonywane z partnerem, w przyszłości dziecko wykona samo. Ważne jest jednak, aby zaangażowanie dziecka też było aktywne, bo w przeciwnym razie nowe struktury myślenia czy działania nie będą uwewnętrznione. Zatem, nowe sposoby rozwiązywania zadań, nowe sposoby koordynacji części własnego myślenia powstają, wychodząc od idei Wygotskiego, w relacjach społecznych, aby później stać się intelektualnymi narzędziami samej jednostki.

Różnica kompetencji a interakcja dorosły - dziecko. Dorośli mają przewagę nad dziećmi: wyższy status, więcej potrafią, mają większe kompetencje w zakresie tworzenia kontekstu uczenia się, w sposób bardziej trafny udzielają wskazówek ${ }^{12}$. Potrafią bardziej adekwatnie wprowadzać trudności i mobilizować do ich pokonywania, mimo że już w wieku przedszkolnym dzieci też są skutecznymi nauczycielami, jeśli same potrafią wykonać zadanie $^{13}$. Kiedy jednak w dziecięcym współdziałaniu pojawi się trudność, może nastąpić tendencja do jej omijania poprzez uproszczenie lub niewykonanie zadania. Przykładem może tu być program "Questionning-asking reading" przygotowany na potrzeby pracy z dziećmi z trudnościami w czytaniu14. Autorzy rozdzielili pomiędzy uczestników programu role niektórych ele-

${ }^{10}$ L.S. Wygotski, Myślenie i mowa, przekł. J. Fleszner, Warszawa 1989.

11 A. Brzezińska, Społeczna psychologia rozwoju, Warszawa 2000, s. 137-142.

$12 \mathrm{G}$. Shugar, Uczestnictwo dzieci w procesach nauczanie - uczenie się, [w:] Z badań nad kompetencja komunikacyjna dzieci, red. B. Bokus, M. Haman, Warszawa 1992; J. Tudge, B. Rogoff, Wpływ rówieśników na rozwój poznawczy, [w:] Dziecko wśród rówieśników i dorostych.

13 E. Pożarowska, Struktura i proces dyskursu dziecięcego w sytuacji zadaniowej, [w:] Z badan nad kompetencją komunikacyjna dzieci, red. B. Bokus, M. Haman, Warszawa 1992.

${ }^{14}$ M. Cole, Cultural Psychology. Once and future discipline, Cambridge 1998. 
mentarnych czynności potrzebnych przy czynności czytania, takich jak: przypominanie celu działalności, zadawanie pytań o sens wspólnie czytanego tekstu i poszczególnych jego części, zadawanie pytań o fonetyczną postać tekstu itp. Dorosły biorący udział we wspólnie wykonywanym zadaniu, jako osoba bardziej kompetentna, pełnił funkcję ogólnego koordynatora czynności. W przypadku, kiedy w spotkaniach nie uczestniczyły osoby dorosłe, dzieci nie dokonywały postępu, ponieważ ułatwiały sobie zadanie i unikały pokonywania trudności. Kreowały sobie sytuacje, w których działały „na skróty” i omijały kłopotliwe zadania.

Istnieją badania, które potwierdzają, że we współpracy z dorosłymi dzieci nie tylko konfrontowane są z wyższymi standardami wykonywanych zadań, ale również otrzymują więcej wyjaśnień, więcej pozytywnych zwrotów i komentarzy; dorośli w większym stopniu werbalizują działania dzieci, przygotowują je do zadania zanim zacznie się je rozwiązywać, dają im możliwość samodzielnego rozwiązania zadania. Dzieci - nauczyciele mają zaś skłonność do negatywnego komentowania działań swoich uczniów, raczej wydają polecenia niż komentują, a w przypadku wystąpienia trudności mają skłonność do wykonania zadania za ucznia ${ }^{15}$. Dorośli także bardziej adekwatnie dopasowują środki pomocnicze do poziomu rozumowania dzieci. To właśnie owo dopasowanie ${ }^{16}$ udzielonej pomocy do rodzaju wykonywanego zadania ma kluczowe znaczenie dla postępu w myśleniu czy działaniu.

Zatem, dorośli lepiej kontrolują i samo zadanie, i sposób myślenia swoich uczniów. Są punktem odniesienia dla podjętych przez dzieci celów i poszukiwania środków do osiągnięcia tych celów, są też w większym stopniu zdolni do planowania i organizowania sytuacji uczenia się, do „wrażliwej kontroli uczenia się"17, to jest do stawiania nowych zadań krok po kroku, w zależności od postępów. „Rozpoznawanie w naturze regularności (...) i doskonalenie zdolności podporządkowania się im oraz kontrolowania procesów, które je tworzą, często (choć nie zawsze) zachodzi podczas kontaktów społecznych pomiędzy osobami mniej dojrzałymi, a tymi, którzy wiedzą więcej". Istnieją jednak okoliczności, które sprawiają, że interakcja edukacyjna dziecko - dziecko ma kilka przewag nad interakcją dorosły - dziecko.

${ }^{15}$ G. Shugar, Uczestnictwo dzieci w procesach nauczanie - uczenie się; N. Dąbrowska, Dzieci jako uczniowie i dzieci jako nauczyciele. Układy interakcyjne nauczyciel - uczeń w procesie wykonywania zadania, [w:] Z badań nad kompetencją komunikacyjna dzieci; J. Tudge, B. Rogoff, Wptyw rówieśników na rozwój poznawczy, [w:] Dziecko wśród rówieśników i dorostych.

16 J. Radziszewska, B. Rogoff, Children's guided participation in planning imaginary errands with skilled adult or peer partners.

17 D. Wood, Spoteczne interakcje jako tutoring, [w:] Dziecko wśród rówieśników i dorostych. 
Dzieci jako nauczyciele mniej kompetentnych rówieśników. Dzieci jako nauczyciele udzielają mniej wskazówek, szybciej się zniechęcają, częściej bezpośrednio pokazują, jak wykonać daną czynność wykonując ją za podopiecznego ${ }^{18}$. Prawdopodobnie brak im wyobrażenia na temat sposobu dochodzenia do rozwiązania zadań przez innych oraz tego, w jaki sposób ułatwić im ich wykonanie. Jednak w literaturze na temat interakcji rówieśniczych często podkreśla się też, że ich zaletą jest między innymi równorzędność statusu, gdzie dzieci mogą spierać się między sobą korzystając z jednakowej pozycji społecznej ${ }^{19}$. U progu szkoły zaczynają argumentować swoje przekonania, dzięki czemu dokonują postępu tak w sferze intelektualnej, nabywając formy logicznego myślenia, jak i uzyskując pełniejsze rozróżnienie między świadomością własnego i cudzego punktu widzenia. Dzieci wiele się uczą od bardziej kompetentnych pod jakimś względem rówieśników, ale wystąpienie $\mathrm{w}$ roli osoby, która sama może mieć przewagę nad kimś mniej kompetentnym ma również pozytywne efekty. Pewne zadania mogą być wykonywane lepiej niż $\mathrm{w}$ interakcji $\mathrm{z}$ dorosłym. I tak, dotyczy to $\mathrm{np}$. ekspresji struktur logicznych, ale też lepszego dopasowywania środków przekazu do odbiorcy wypowiedzi w przypadku jej kierowania do dzieci mniej kompetentnych pod jakimś względem w porównaniu z wypowiedziami kierowanymi do dorosłych. Gdzie indziej20 zaznacza się, iż „domykanie" procesów rozwojowych rozpoczętych w interakcjach z dorosłymi prawdopodobnie odbywa się $\mathrm{w}$ samodzielnie wykonywanych zadaniach; dzieci dążą do uzyskania samodzielnej kontroli nad przyswajanymi treściami, a sytuacja uczenia innych bardzo temu sprzyja.

Wpływ pozytywnego oddziaływania interakcji z mniej kompetentnym rówieśnikiem zademonstrowano $\mathrm{w}$ niektórych badaniach $\mathrm{z}$ udziałem dzieci $\mathrm{w}$ wieku przedszkolnym. $\mathrm{W}$ jednym $\mathrm{z}$ nich ${ }^{21}$ dzieci układały $\mathrm{w}$ narracje przedstawione na planszach obrazki. Obserwowano zdolność do tworzenia linii i pola narracji, a także różnic $\mathrm{w}$ tym zakresie $\mathrm{w}$ relacji do różnych odbiorców. $\mathrm{W}$ innych badaniach ${ }^{22}$ dzieci $\mathrm{w}$ wieku wczesnoszkolnym postawione były przed zadaniem wyjaśniania różnym odbiorcom określonych pojęć, tym razem bez możliwości posługiwania się konkretnymi obrazkami czy przedmiotami. Dzieci musiały zatem dokonywać operacji intelektualnych w oderwaniu od przedmiotu swojej refleksji. W obydwu wypadkach

${ }_{18}$ G. Shugar, Uczestnictwo dzieci w procesach nauczanie - uczenie się.

19 J. Piaget. Studia z psychologii dziecka; W. Radziwiłłowicz, Rozwój poznawczy dzieci w młodszym wieku szkolnym; J. Tudge, B. Rogoff, Wptyw rówieśników na rozwój poznawczy.

${ }^{20}$ D. Wood, Spoteczne interakcje jako tutoring.

${ }^{21}$ B. Bokus, Światy fabuty w narracji dziecięcej.

22 M. Marchow, Społeczna geneza dowolnej kontroli myślenia u dzieci w wieku wczesnoszkolnym, Poznań 2004. 
dzieci kierując wypowiedzi do mniej kompetentnych rówieśników potrafiły uwzględnić informacje, których mógłby nie mieć partner interakcji, mniej koncentrowały się na własnych preferencjach, przy czym wypadały pod tym względem korzystniej niż w interakcjach z dorosłymi.

Gdzie indziej $w$ badaniach nad tutoringiem ${ }^{23}$ zauważa się, że wystąpienie $\mathrm{w}$ roli tutora wzmaga kompetencje $\mathrm{w}$ zakresie zdolności do uczenia się (tzw. academic skills). Dzieci uczą się monitorować proces uczenia się i myślenia, dowolnie kierować uwagą, podejmować więcej prób rozwiązania danego zadania, $\mathrm{z}$ czasem też dokonują transferu nabytych umiejętności na nowe zadania i sytuacje. Procesy zaangażowane $\mathrm{w}$ monitorowanie myślenia i działania, związane z procesem uświadamiania własnego myślenia, nabywaniem stosunku do niego, możliwością porównywania efektu działania z przedsięwziętym celem, wiąże się z rozwojem tzw. procesów metapoznawczych ${ }^{24}$. Uważa się, że determinują one sukcesy szkolne dzieci25. Właśnie ten stosunek do własnego myślenia jest tu kluczowy. U progu szkoły dzieci dokonują znaczącego postępu w zakresie dowolnego kierowania swoim zachowaniem, afektem i myśleniem, co umożliwia regularną i systematyczną naukę szkolną ${ }^{26}$. Nie pozostaje to bez związku z jednoczesnym pojawieniem się form logicznego myślenia $\mathrm{i}$ ich trenowaniem $\mathrm{w}$ relacjach rówieśniczych ${ }^{27}$. Badania nad tzw. teorią umysłu unaoczniają ten proces dokonywania rozróżnienia między własnym i cudzym myśleniem oraz jego związek ze wzrastającymi możliwościami nawiązywania interakcji z innymi, w tym - interakcji edukacyjnych.

\section{Dziecięca teoria umysłu a funkcjonowanie dzieci $w$ interakcjach edukacyjnych}

Koncept teorii umysłu nie jest tożsamy z teorią wspomnianych powyżej procesów metapoznawczych ani też wywodzących się z teorii Wygotskiego idei społecznego pochodzenia wewnątrzpsychicznych systemów regulujących myślenie. Odnoszą się one do nieco innych odniesień teoretycznych i innych obszarów zastosowań. Jednak ze względu na wspólne elementy,

${ }^{23}$ D. Fuchs, L.S. Fuchs I.P. Burish, Peer Assisted learning Strategies, s. 85-91.

24 Z. Nęcka, Inteligencja: struktura - geneza - funkcje, Sopot 2003.

25 J. Astington, Theory of Mind, Humpty Dumpty and the Icebox, Human Development, 1998, 41, s. 30-39.

${ }^{26}$ L.S. Wygotski, Kryzys siódmego roku życia, [w:] L. Wygotski. Wybrane prace psychologiczne II, red. A. Brzezińska, M. Marchow, Poznań 2002.

27 J. Piaget. Studia z psychologii dziecka; W. Radziwiłłowicz, Rozwój poznawczy dzieci w młodszym wieku szkolnym. 
w badaniach występują one jako pojęcia pokrewne czy łączone ze sobą, szczególnie $\mathrm{w}$ dobie renesansu idei Wygotskiego i badań nad społecznym pochodzeniem systemów kontrolujących procesy psychiczne ${ }^{28}$. Tutaj, łącząc te pojęcia i odnosząc je do tutoringu rówieśniczego, chcę zwrócić uwagę na dwie kwestie.

Po pierwsze, nieobecność procesów określanych jako teoria umysłu, czasem zwanej zdolnością do mentalizacji ${ }^{29}$ ogranicza lub uniemożliwia uczestniczenie w sytuacjach społecznego uczenia się. Szczególnie sytuacja tutoringu rówieśniczego wymagająca aktywnego dopasowania do sytuacji interpersonalnej może być tu wykluczona czy nieefektywna. Po drugie, zaangażowanie $\mathrm{w}$ interakcje rówieśnicze o charakterze tutoringu może z kolei przyczyniać się do ekspresji i rozwoju teorii umysłu, a konsekwencji - do usprawnienia społecznego funkcjonowania dziecka w ogóle.

Zatem, w uproszczeniu, można by powiedzieć, że teoria umysłu to tyle, co zdolność do rozumienia i uwzględniania różnic między własnym i cudzym punktem widzenia. Młodsze dzieci są przekonane, że inni znają ich myśli, przypisują innym własne przekonania, nie rozumieją, że ktoś opierając się na innych niż one same przesłankach, może formułować też inne sądy. Z czasem się to zmienia i jak wskazują badania 5-letnie dzieci dysponują teorią umysłu, która pozwala im adekwatnie przewidywać sposób myślenia innych. Teoria umysłu to właściwość myślenia wyrastająca z relacji społecznych. To sposób organizacji doświadczenia, który uważa się na pochodną kontaktów międzyludzkich i kontaktom tym służący, uważany niekiedy za podstawę komunikowania się ${ }^{30}$. Od pierwszych dni życia człowiek zanurzony jest $\mathrm{w}$ wymianie $\mathrm{z}$ innymi, staje przed koniecznością dopasowywania się do interakcji, zdolny jest do jakichś pierwotnych form odwzorowywania, wzajemności komunikatów i dopasowywania się do działań innych, przewidywania do czego dążą i na czym im zależy ${ }^{31}$. Dzięki temu możliwa jest wspólna organizacja działania, komunikowanie się, a na późniejszych etapach rozwoju - skoordynowana współpraca, w której następuje zamierzony podział ról i zadań. $\mathrm{W}$ interakcji z drugim człowiekiem trudno z całą pewnością określić jego motywy, intencje, sposób wnioskowania. Lukę tę uzupełnia właśnie teoria umysłu, która dalej trenowana jest $\mathrm{w}$ tychże interakcjach. Idzie ona $\mathrm{w}$ parze $\mathrm{z}$ rozwojem empatii, rozumieniem skutków

${ }^{28}$ M. Białecka-Pikul, Narodziny i rozwój refleksji nad myśleniem, Kraków 2012; M. Marchow, Społeczna geneza dowolnej kontroli myślenia u dzieci.

${ }^{29}$ M. Białecka-Pikul, Narodziny i rozwój refleksji nad myśleniem.

${ }^{30}$ M. Haman, Dziecięca teoria umystu jako podstawa komunikowania się, [w:] Z badań nad kompetencja komunikacyjna dzieci.

${ }^{31}$ M.H. Bornstein, Pomiędzy opiekunami a ich potomstwem: dwa rodzaje interakcji $i$ ich konsekwencje dla rozwoju poznawczego, [w:] Dziecko wśród rówieśników i dorostych. 
własnych działań dla innych, a także ze zdolnością do modyfikacji własnych komunikatów kierowanych do innych w oparciu o wiedzę o nich ${ }^{32}$.

Dobitnie potwierdzają to badania nad autyzmem dziecięcym, gdzie stwierdza się deficyty w tym właśnie obszarze. Dzieci dotknięte autyzmem nie naśladują innych, nie wcielają się $\mathrm{w}$ ich role (np. w zabawie symbolicznej), nie przyjmują ich punktu widzenia, nie uwzględniają go w swoim działaniu, nie kierują się empatią. Ich myślenie charakteryzuje się, mówiąc $\mathrm{w}$ uproszczeniu, deficytem zdolności komunikacyjnych i brakiem symbolicznej reprezentacji i ekspresji uczuć. Jednak istnieją dzieci autystyczne, które osiągają dobre wyniki $\mathrm{w}$ testach inteligencji i dobrze radzą sobie $\mathrm{z}$ niektórymi intelektualnymi zadaniami ${ }^{33}$. Tam, gdzie $\mathrm{w}$ grę wchodzi uwzględnianie złożonych motywów wewnętrznych innych ludzi, dzieci te pozostają bezradne. Autyzm bywa określony jako, od strony poznawczej, uszkodzenie procesów metareprezentowania, a nie reprezentowania struktur rzeczywistości rozumianych jako np. zdolność do wykonywania określonych operacji. Uznaje się niepowodzenia dzieci autystycznych w wykonywaniu zadań $\mathrm{z}$ zakresu teorii umysłu za jedną $\mathrm{z}$ cech zaburzenia ${ }^{34}$, gdzie nawet przy obecności jakiejś formy teorii umysłu występuje często trudność z przeniesieniem jej na codzienne sytuacje.

Zatem, brak lub deficyt w zakresie teorii umysłu ogranicza lub uniemożliwia uczestniczenie $w$ interakcjach edukacyjnych, jako że pośredniczy ona w wymianie komunikatów, uwag, wskazówek, określaniu celów działania i negocjowania ich $\mathrm{z}$ innymi, $\mathrm{w}$ działaniu grupowym lub zespołowym. Szczególnie to ostatnie odgrywa znaczącą rolę $\mathrm{w}$ rozwoju dzieci w pierwszych klasach szkoły podstawowej. Teoria umysłu powiązana jest bowiem z pragmatycznym aspektem posługiwania się własnym myśleniem, z jego uświadamianiem, kontrolowaniem, celowym i rozumnym stosowaniem w danym kontekście, czy też w różnych kontekstach.

Dysponowanie wiedzą o umyśle to jedno, a posługiwanie się tą wiedzą $\mathrm{w}$ praktyce to drugie. Pojawiająca się kompetencja w zakresie rozumienia cudzych intencji i motywów nie oznacza, że w klasie czy zespole rówieśniczym, i to w różnych sytuacjach i kontekstach, dzieci będą z niej robiły pożytek. Często może być tak, że potencjalnie taka zdolność istnieje, jednak pozostaje ukryta ze względu na brak okazji do jej ujawniania czy ćwiczenia. I jeśli nawet, jak chcą niektórzy, teoria umysłu 5- czy 6-latka ma już postać

${ }^{32}$ H.R. Schaeffer, Psychologia dziecka, Warszawa 2005.

${ }_{33} \mathrm{M}$. Haman, Dziecięca teoria umystu.

${ }^{34}$ M. Scheeren i in., Rethinking theory of mind in high-functioning autism spectrum disorder, Journal of Child Psychology \& Psychiatry, 2013, 54, 6, s. 628-635. 
podobną do teorii umysłu dorosłego człowieka ${ }^{35}$, to nawet dorośli w praktyce nie zawsze $\mathrm{z}$ niej korzystają $\mathrm{i} \mathrm{w}$ wielu sytuacjach uwzględniają jedynie swój punkt widzenia oraz swoją wiedzę o przedmiotach, bez dopasowywania instrukcji do wiedzy partnera interakcji. Tym bardziej dotyczyć to może dzieci 6- czy 7-letnich, dla których zdolność do rozumienia stanów umysłowych innych osób i rozróżniania ich od własnych przekonań jest stosunkowo nową zdolnością. Występowanie zaś $\mathrm{w}$ roli tutora czy nauczyciela promuje wysiłek związany z uruchomieniem teorii umysłu, z dopasowywaniem instrukcji i wskazówek do potrzeb oraz poziomu kompetencji innego człowieka. Uczenie innych dzieci wymusza monitorowanie interakcji społecznych w większym stopniu niż przyjęcie roli mniej kompetentnego, często biernego, ucznia.

Jednocześnie chciałabym podkreślić, że zdolność do korzystania z sytuacji uczenia się $\mathrm{w}$ społecznym kontekście nie jest tożsama $\mathrm{z}$ dysponowaniem łatwością w pozaedukacyjnych sytuacjach społecznych, takich jak pozycja $\mathrm{w}$ klasie czy łatwość nawiązywania kontaktów, jednak za jednym i drugim stoi podobny mechanizm. $Z$ tego też powodu rozwój teorii umysłu dokonujący się na przykład w sytuacji tutoringu rówieśniczego może być przesłanką do jej transferu na inne sytuacje społeczne.

\section{Tutoring rówieśniczy i rozwój mechanizmów uczenia się}

Ważne jest uwzględnienie aktualnego etapu rozwoju dziecka, do którego odnosi się dana analiza teoretyczna lub strategia edukacyjna. W okresie wczesnoszkolnym dzieci stoją przed wyzwaniem nadawania porządku własnemu myśleniu, ustalania pewnej hierarchii w wyodrębnianych treściach, do planowania działań z wyprzedzeniem, przewidywania konsekwencji przyjętych założeńn ${ }^{36}$. W tym świetle nauka czytania, pisania i podstaw matematyki staje się nie tylko narzędziem ułatwiającym naukę innych treści (to jest tych, które wymagają umiejętności czytania, pisania i liczenia). Istnieje wiele danych, które wskazują, że narzędzia te pełnią funkcję środków wspomagających nową organizację myślenia, nowy stosunek do własnych umiejętności, czy też - nowy sposób posługiwania się strategiami metapoznawczymi. Czytanie czy liczenie wymagają bowiem przeniesienia operacji intelektualnych na poziom abstrakcyjny, oderwany od konkretnych obiek-

${ }^{35}$ B. Keysar, Sh. Lin, J. Barr, Limits on theory of mind use in adults, Cognition, 2003, 89, s. 25-41.

36 J. Piaget. Studia z psychologii dziecka; L.S. Wygotski, Myślenie i mowa; W. Radziwiłłowicz, Rozwój poznawczy dzieci w młodszym wieku szkolnym; M. Marchow, Społeczna geneza dowolnej kontroli myślenia u dzieci. 
tów, od bezpośredniego kontekstu interpersonalnego, który dostarcza natychmiastowych informacji zwrotnych $\mathrm{w}$ zakresie znaczenia komunikatów dziecięcych. Zatem, wraz z dokonaniem postępu w zakresie operowania strategiami o charakterze metapoznawczym zwiększają się też kompetencje komunikacyjne dzieci, a wraz z nimi zasoby użyteczne w sytuacjach uczenia się w kontekście społecznym.

Jednocześnie, uwzględniając tematykę wyznaczoną ramami niniejszego artykułu, zjawisko tekstu trzeba traktować nie tylko jako obiekt mechanicznej obróbki, ale jak twór pozostający na usługach komunikacji międzyludzkiej. Posługiwanie się nim jest oparte na jakiejś wiedzy o odbiorcach i w tym sensie też sam stanowi przedłużenie procesów rozwoju kompetencji komunikacyjnej ${ }^{37}$. Ze względu na swój abstrakcyjny charakter, proces przyswajania pisma dokonuje się $\mathrm{w}$ tym samym momencie, $\mathrm{w}$ którym człowiek nabywa kompetencji w zakresie odnoszenia się nie tylko do konkretnych osób i obiektów w konkretnej sytuacji, ale do klas obiektów posiadających ogólne właściwości. Przyswojenie i posługiwanie się mową pisaną jest kolejnym etapem na drodze do uwolnienia myślenia od władzy bezpośredniej sytuacji38. Stopniowo staje się ono mniej zależne od kontekstu, mniej sztywne i impulsywne, dosłowne i konkretne ${ }^{39}$.

Nawiązując do przedstawianych powyżej myśli, chcę tu przywołać przykład jednego z programów doskonalenia czytania, opartych na tutoringu rówieśniczym $w$ warunkach klasy szkolnej ${ }^{40}$. W programie tym dzieci łączone są w pary: mniej i bardziej kompetentna osoba pracują razem przez kilka tygodni, co najmniej trzy razy w tygodniu przez kilkadziesiąt minut. Każde dziecko naprzemiennie pełni rolę raz tutora, raz ucznia (czyli dzieci słabsze też pełnią w tych parach funkcję tutora). Dzieci ćwiczą trzy rodzaje pracy z tekstem: płynne czytanie, umiejętność streszczania i podsumowywania fragmentów tekstu oraz przewidywanie dalszego ciągu tekstu. Szczególnie dwa ostatnie ćwiczenia odnoszą się do refleksyjnego operowania treścią tekstu, do nadawania mu porządku, promowania wyciągania wniosków z treści, które zostały przedstawione. Rodzaj ćwiczeń jest narzucony przez nauczyciela, sposób instruowania się nawzajem przez dzieci w parach - również. Przedstawione efekty tych działań (i badań) są takie, że znakomita większość dzieci, w tym - uczniowie zdolni i bardziej kompetentni - do-

37 J. Łuczyński, Mowa pisana jako środek komunikowania się, [w:] Z badań nad kompetencja komunikacyjna dzieci.

${ }^{38}$ L.S. Wygotski, Wczesne dzieciństwo.

${ }^{39}$ D. Wood, Spoteczne interakcje jako tutoring.

${ }^{40}$ D. Fuchs, L.S. Fuchs, I.P. Burish, Peer Assisted learning Strategies, s. 85-91; K.L. McMaster, D. Fuchs, L.S. Fuchs, Promises and Limitations of Peer, s. 97-112. 
konuje widocznego postępu w zakresie ćwiczonych umiejętności. Ważniejszy jeszcze, z punktu widzenia tematu niniejszego artykułu, wydaje się taki efekt, że postęp $\mathrm{w}$ zakresie rozumienia i przewidywania dalszego ciągu tekstu pozytywnie związany był z pełnieniem roli tutora ${ }^{41}$ (efekt ten nie dotyczył postępu w zakresie samej płynności czytania). Zatem tam, gdzie w grę wchodzi organizowanie treści i nadawanie mu porządku, uczenie innych może dodatkowo wspomagać własną kontrolę nad procesami myślenia.

Kolejny interesujący wniosek dotyczy programu wspomagającego umiejętności w zakresie matematyki ${ }^{42}$. Stwierdzono, iż postępy są większe, kiedy dzieci dochodzą do rozwiązań metodą elaboracji (poszukując samodzielnie rozwiązania, sprawdzając różne możliwości itp.). Dzieci - tutorzy mają skłonność do natychmiastowego poprawiania i udzielania prawidłowej odpowiedzi, w miejsce wyczekania, aż uczeń sam znajdzie odpowiedź (co jest zgodne $\mathrm{z}$ wnioskami z badań podanych $\mathrm{w}$ poprzednich paragrafach). Podjęto się zatem instruowania dzieci - tutorów $\mathrm{w}$ zakresie instruowania elaboracyjnego, co zwiększyło i postać udzielanych instrukcji, i efektywność uczenia się dzieci - uczniów. Stwierdzono też, że starsze dzieci szybciej przyswajały istotę strategii elaboracyjnych. Znaczy to tyle, że postęp w zakresie umiejętności monitorowania procesu uczenia się związany jest $\mathrm{z}$ wiekiem, w związku z tym można go również traktować jako właściwość poddaną procesom rozwoju. Dzieci nieobjaśnione, w jaki sposób instruować inne dzieci, miały tendencję do chaotycznego i nieskutecznego wydawania instrukcji. Z tego wniosek, że samo wydawanie instrukcji, sposób monitorowania procesu uczenia się też $w$ jakimś sensie może być traktowany jako obszar strefy najbliższego rozwoju - w zakresie monitorowania procesów uczenia się i stosowania ich w kontekście społecznym.

\section{Podsumowanie}

Dzieci odnoszą korzyść zarówno z sytuacji, w której występują w roli uczniów bardziej kompetentnych partnerów, ponieważ uzyskują lepsze wskazówki jak wykonać zadanie, szczególnie takie, które jest dla nich zupełnie nowe, jak również z tego, że same pełnią rolę nauczycieli, ponieważ mogą trenować posiadane już umiejętności oraz poddawać kontroli samą sytuację uczenia się i sposób myślenia swoich uczniów. W roli nauczycieli nabywają większych umiejętności w zakresie uwzględniania wiedzy partne-

${ }^{41}$ Tamże, s. 88.

42 Tamże, s. 85-91. 
rów interakcji, muszą zmieniać i dostosowywać instrukcję do drugiej osoby. Wraz z wiekiem zwiększają się także ich zdolności do elaboracyjnego podejścia do rozwiązania zadnia przez innych: pozwalają partnerom samodzielnie znaleźć rozwiązanie $\mathrm{w}$ miejsce wykonywania zadania za nich. Uczą się, jak wspierać, zachęcać motywować do ukończenia zadania. W konsekwencji, stają się też bardziej kompetentne w tym zakresie jeśli chodzi o stosunek do własnego procesu uczenia się oraz możliwości kontroli nad relacją pomiędzy własną myślą i jej organizacją. Stają się istotami pełniej korzystającymi z sytuacji uczenia się $\mathrm{w}$ interakcjach społecznych, przygotowanymi na współpracę z różnymi osobami.

Zadanie nauczyciela $\mathrm{w}$ tej strategii polega na monitorowaniu instrukcji wydawanych przez dzieci, dbaniu o to, aby były one dopasowane do charakteru zadań oczekiwanych na danym poziomie rozwoju, dbaniu i egzekwowaniu przyjętych standardów. Ponadto, dbając o koordynację grupy i np. wymienność ról tutor - uczeń, dorosły dba o umożliwienie wszystkim dzieciom skorzystania zarówno $\mathrm{z}$ indywidualnego podejścia do procesu uczenia się, jak też z doświadczenia siebie jako osoby monitorującej proces uczenia się. W naturalnych warunkach nie zawsze może to być osiągalne.

\section{BIBLIOGRAFIA}

Astington J., Theory of Mind, Humpty Dumpty and the Icebox, Human Development, 1998, 41.

Białecka-Pikul M., Narodziny i rozwój refleksji nad myśleniem, Wydawnictwo U, Kraków 2012.

Bokus B., Światy fabuty w narracji dziecięcej, Wydawnictwo Energeia, Warszawa 2000.

Bornstein M.H., Pomiędzy opiekunami a ich potomstwem: dwa rodzaje interakcji $i$ ich konsekwencje dla rozwoju poznawczego, [w:] Dziecko wśród rówieśników i dorostych, red. A. Brzezińska, G. Lutomski, B. Smykowski, Wydawnictwo Zysk i S-ka, Poznań 1995.

Brzezińska A., Społeczna psychologia rozwoju, Wydawnictwo Naukowe Scholar, Warszawa 2000.

Brzezińska A., Tutoring w edukacji: kaprys, konieczność czy szansa dla ucznia i nauczyciela? [w:] Tutoring młodych uchodźców, Stowarzyszenie Praktyków Kultury, publikacja internetowa, Warszawa 2012.

Cole M., Cultural Psychology. Once and future discipline, Harvard University Press, Cambridge 1998.

Dąbrowska N., Dzieci jako uczniowie i dzieci jako nauczyciele. Układy interakcyjne nauczyciel uczeń w procesie wykonywania zadania [w:] Z badań nad kompetencja komunikacyjna dzieci, red. B. Bokus, M. Haman, Wydawnictwo Energeia, Warszawa 1992.

Forman E.A., Cazden C.B., Myśl Wygotskiego a edukacja: wartości poznawcze wspótpracy z rówieśnikami, [w:] Dziecko wśród rówieśników i dorostych, red. A. Brzezińska, G. Lutomski, B. Smykowski, Wydawnictwo Zysk i S-ka, Poznań 1995. 
Fuchs D., Fuchs L.S., Burish P., Peer-Assisted Learning Strategies: An evidence-based practice to promote reading achievement, Learning Disabilities Research and Practice, 2000, 15.

Haman M., Dziecięca teoria umystu jako podstawa komunikowania się [w:] Z badań nad kompetencja komunikacyjna dzieci, red. B. Bokus, M. Haman, Wydawnictwo Energeia, Warszawa 1992.

Keysar Sh., Lin D., Barr J., Limits on theory of mind use in adults, Cognition, 2003, 89.

Ligęza M., Rola pytań dzieci 3-6-letnich w inicjowaniu i podtrzymywaniu rozmowy $z$ dorostym, [w:] Z badań nad kompetencją komunikacyjna dzieci, red. B. Bokus, M. Haman, Wydawnictwo Energeia, Warszawa 1992.

Łuczyński J., Mowa pisana jako środek komunikowania się, [w:] Z badań nad kompetencją komunikacyjna dzieci, red. B. Bokus, M. Haman, Wydawnictwo Energeia, Warszawa 1992.

Marchow M., Społeczna geneza dowolnej kontroli myślenia u dzieci w wieku wczesnoszkolnym, niepublikowana rozprawa doktorska, UAM, Poznań 2004.

McMaster K.L., Fuchs D., Fuchs L.S., Promises and Limitations of Peer - Assisted Learning Strategies in Reading, Learning Strategies: A contemporary Journal, 2007, 5(2).

Nęcka Z., Inteligencja: struktura - geneza - funkcje, Gdańskie Wydawnictwo Psychologiczne, Sopot 2003.

Nowak J., Tutoring rówieśniczy jako wsparcie rozwoju poznawczego dziecka, [w:] Dziecko $i$ dorosty w koncepcji pedagogicznej Marii Montessori - teoria i praktyka, red. B. Surma, Wydawnictwo Palatum-Ignatianum, Łódź-Kraków 2009.

Piaget J., Studia z psychologii dziecka, PWN, Warszawa 1966.

Pożarowska E., Struktura i proces dyskursu dziecięcego w sytuacji zadaniowej, [w:] Z badań nad kompetencja komunikacyjna dzieci, red. B. Bokus, M. Haman, Wydawnictwo Energeia, Warszawa 1992.

Radziwiłłowicz W., Rozwój poznawczy dzieci w młodszym wieku szkolnym, Oficyna Wydawnicza Impuls, Kraków 2004.

Radziszewska J., Rogoff B., Children's guided participation in planning imaginary errands with skilled adult or peer partners, Developmental Psychology, 1991, 27, 3.

Rycielski P., Efektywność kształcenia w programach tutoringu rówieśniczego, [w:] Tutoring młodych uchodźców, Stowarzyszenie Praktyków Kultury, Warszawa 2012.

Scheeren M., De Rosnay H.M., Koot S., Begeer S., Rethinking theory of mind in highfunctioning autism spectrum disorder, Journal of Child Psychology \& Psychiatry, 2013, 54,6 .

Shugar G., Uczestnictwo dzieci w procesach nauczanie - uczenie się, [w:] Z badań nad kompetencja komunikacyjna dzieci, red. B. Bokus, M. Haman, Wydawnictwo Energeia, Warszawa 1992.

Schaffer H.R., Psychologia dziecka, Wydawnictwo Naukowe PWN, Warszawa 2005.

Słonczewska E., Przeciwstawianie się partnerowi. Rola zjawiska w rozwoju interakcji społecznej dzieci w wieku przedszkolnym, [w:] Z badań nad kompetencją komunikacyjna dzieci, red. B. Bokus, M. Haman, Wydawnictwo Energeia, Warszawa 1992.

Tudge J., Rogoff B., Wptyw rówieśników na rozwój poznawczy, [w:] Dziecko wśród rówieśników $i$ dorostych, red. A. Brzezińska, G. Lutomski, B. Smykowski, Wydawnictwo Zysk i S-ka, Poznań 1995.

Wood D., Społeczne interakcje jako tutoring, [w:] Dziecko wśród rówieśników i dorostych, red. red. A. Brzezińska, G. Lutomski, B. Smykowski, Wydawnictwo Zysk i S-ka, Poznań 1995.

Wygotski L.S., Narzędzie i znak w rozwoju dziecka, PWN, Warszawa 1971. 
Wygotski L.S., Myślenie i mowa, przekł. J. Fleszner, PWN, Warszawa 1989.

Wygotski L.S., Wczesne dzieciństwo, [w:] L. Wygotski. Wybrane prace psychologiczne II, red. A. Brzezińska, M. Marchow, Wydawnictwo Zysk i S-ka, Poznań 2002.

Wygotski L.S., Kryzys siódmego roku życia, [w:] L. Wygotski. Wybrane prace psychologiczne II, red. A. Brzezińska, M. Marchow, Wydawnictwo Zysk i S-ka, Poznań 2002. 